\title{
The great Sumatra-Andaman earthquakes - Imaging the boundary between the ruptures of the great 2004 and 2005 earthquakes
}

\author{
Dieter Franke $^{\mathrm{a}, *}$, Michael Schnabel ${ }^{\mathrm{a}}$, Stefan Ladage ${ }^{\mathrm{a}}$, David R. Tappin ${ }^{\mathrm{b}}$, Soenke Neben ${ }^{\mathrm{a}}$, \\ Yusuf S. Djajadihardja ${ }^{c}$, Christian Müller ${ }^{\mathrm{a}}$, Heidrun Kopp ${ }^{\mathrm{d}}$, Christoph Gaedicke ${ }^{\mathrm{a}}$ \\ ${ }^{a}$ Federal Institute for Geosciences and Natural Resources (BGR), Stilleweg 2, 30655 Hannover, Germany \\ ${ }^{\mathrm{b}}$ British Geological Survey, Kingsley Dunham Centre, Keyworth, Nottingham, NG12 5 GG, United Kingdom \\ c Agency for the Assessment \& Application of Technology (BPPT), Jl. M.H. Thamrin no. 8, Jakarta 10340, Indonesia \\ d IFM-Geomar, Wischhoffstr. 1-3, Kiel, Germany
}

Received 27 April 2007; received in revised form 28 January 2008; accepted 28 January 2008

Editor: R.D. van der Hilst

\section{Abstract}

Segmentation along convergent margins controls earthquake magnitude and location, but the physical causes of segment boundaries, and their impact on earthquake rupture dynamics, are still poorly understood. One aspect of the 2004 and 2005 great Sumatra-Andaman earthquakes is their abrupt termination along a common boundary. This has led to speculation on the nature of the boundary, its origin and why it was not breached.

For the first time the boundary has been imaged and, with newly acquired marine geophysical data, we demonstrate that a ridge on the subducting Indo-Australian oceanic crust may exert a control on margin segmentation. This suggests a lower plate influence on margin structure, particularly its segmentation. The ridge is masked by the sedimentary cover in the trench. Its most likely trend is NNE-SSW. It is interpreted as a fracture zone on the subducting oceanic plate. A ramp or tear along the eastern flank of the subducting fracture zone beneath Simeulue Island may be considered as intensification factor in terms of rupture propagation barrier.

(C) 2008 Elsevier B.V. All rights reserved.

Keywords: subduction; earthquakes; segmentation; seismic data; Sumatra

\section{Introduction}

Rupture propagation during earthquakes along convergent margins may commonly be confined to discrete along-strike structural segments. However, it is recognised that rupture propagation across such segment boundaries can result in megathrust earthquakes of considerable destructive power that may generate transoceanic tsunami. The control on earthquake propagation exerted by segment boundaries is well established (Spence, 1977; Ando, 1975) but the physical causes are poorly understood. As a result we cannot fully determine seismic and tsunami hazard along convergent margins globally. Several

* Corresponding author. Tel.: +49 511643 3235; fax: +49 5116433663 .

E-mail address: Dieter.Franke@bgr.de (D. Franke). mechanisms are recognised as influencing segmentation. These 39 include: discontinuities in the geometry of the subducting plate 40 such as slab tears (Spence, 1977; Aki, 1979); topographic 41 anomalies within the subducting plate, such as ridges, fracture 42 zones and seamount chains (Kodaira et al., 2000; Cummins et al., 43 2002; Bilek et al., 2003; Collot et al., 2004), major structures 44 crossing the over-riding plate (Ryan and Scholl, 1993; Collot et al., 45 2004) and large-scale variations in the buoyancy of the subducting 46 plate related to its thermal age (Yáñez and Cembrano, 2004). $\quad 47$

In the instance of the great Indian Ocean earthquakes of 48 2004-5 the southern boundary of the December 26th 200449 event is clearly delineated (e.g. Ammon et al., 2005; Bilham, 50 2005; Krüger and Ohrnberger, 2005; Lay et al., 2005; Gahalaut 51 et al., 2006). Significantly, this boundary also delineates the 52 northern termination of the March 28th 2005 earthquake (e.g. 53 
Ammon, 2006; Subarya et al., 2006). A large-scale structure near Simeulue Island (Fig. 1) has been suggested as a control on the ruptures, but its specific nature is unknown. Singh et al. (2005) and Kamesh Raju et al. (2007) propose an upper plate control on the segment boundary with the West Andaman Fault as a key structure controlling rupture propagation. DeShon et al. (2005) propose that the boundary of the southern Andaman microplate, in the vicinity of Simeulue Island is a diffuse deformation zone, and that this developing plate boundary served as a barrier to rupture propagation. Dewey et al. (2007) propose a lower plate control, suggesting that a distortion of the plate interface at depth beneath the forearc may be the cause. More specifically, Subarya et al. (2006) suggest that a boundary has formed due to distortion of the plate interface, related to a north-south trending fracture zone on the incoming oceanic plate.

The aim of this study, therefore, is to characterize the plate interface and structural architecture in the vicinity of the segment boundary between the December 26th 2004 and March 28th 2005 mainshocks. To this end, during 2006, we acquired swath bathymetry, multichannel reflection seismic (MCS), and wide-angle/refraction seismic data. Along trench-parallel pro- 75 files these data image the oceanic plate subducting beneath the 76 forearc as well as upper plate structures. On the oceanic plate 77 there is a broad $\mathrm{N}-\mathrm{S}$ trending ridge entering the accretionary 78 wedge SW of Simeulue. The influence of this ridge on segmen- 79 tation of the upper plate is discussed.

\section{Tectonic setting}

Along the convergent margin off Sumatra the oceanic Indo- 82 Australian Plate subducts under the Eurasian Plate (Fig. 1). As 83 the former plate moves northward, convergence becomes 84 increasingly oblique from south to north. In the vicinity of the 85 December 2004 epicentre the azimuth of convergence is $\mathrm{N} 10^{\circ} \mathrm{E} 86$ at $4^{\circ} \mathrm{N}, 95^{\circ} \mathrm{E}$, (Delescluse and Chamot-Rooke, 2007). The result 87 is large-scale strain partitioning with trench-normal and trench- 88 parallel shear components. Along the leading edge of the 89 Eurasian Plate, the trench-parallel shear results in large-scale, 90 dextral strike-slip fault systems within the forearc basins and on 91 Sumatra. Along the plate margin continental sliver plates have 92 formed (Malod and Kemal, 1996; Simandjuntak and Barber, 93

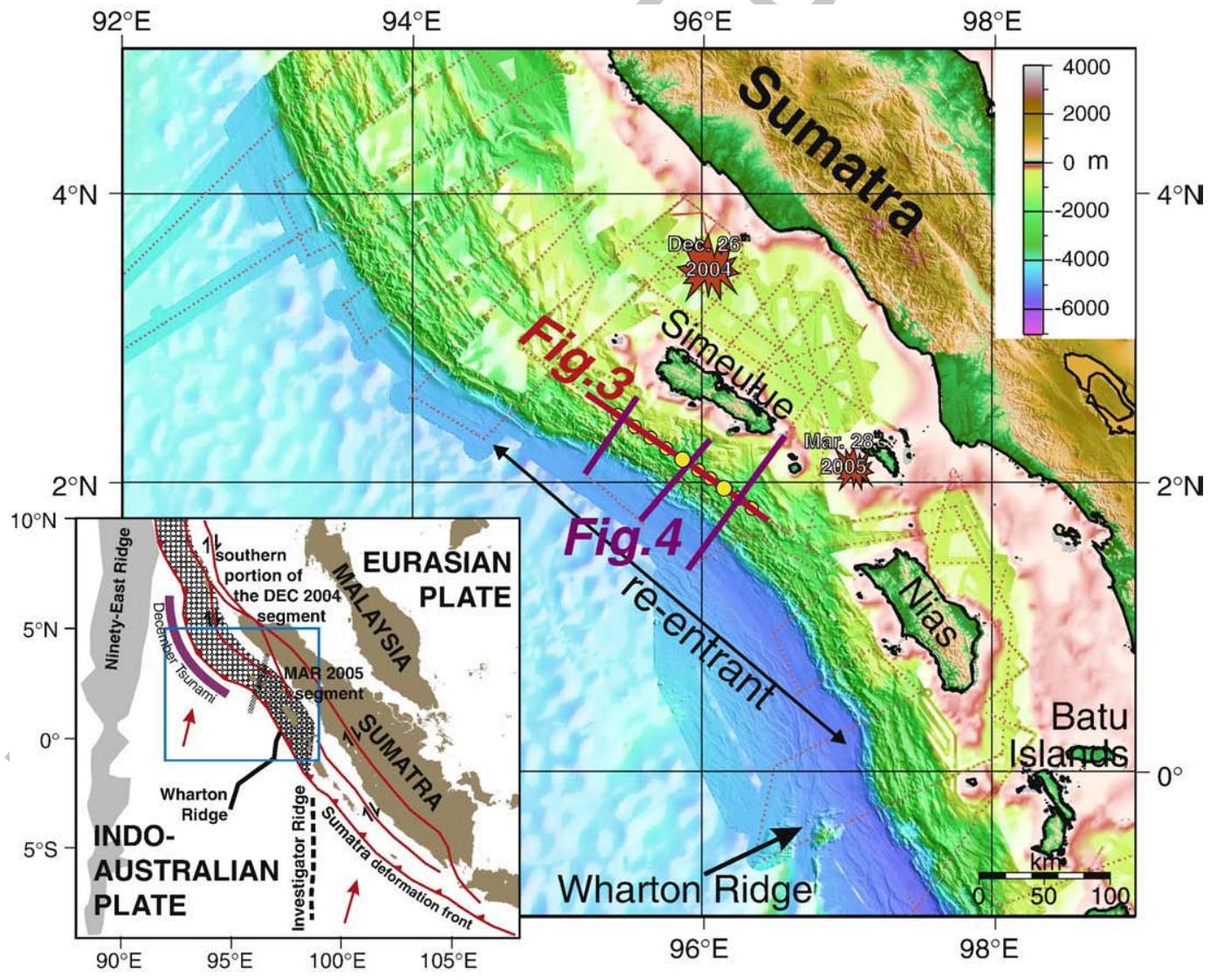

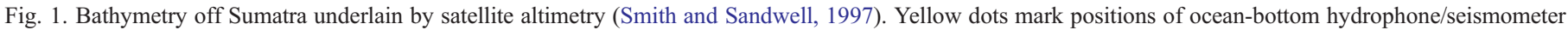

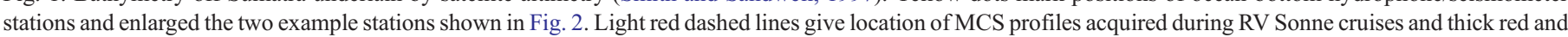

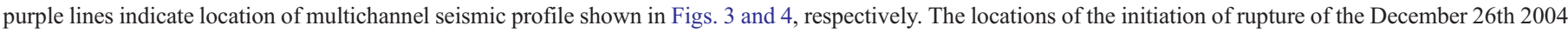

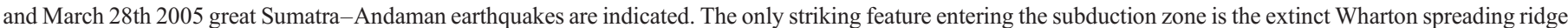

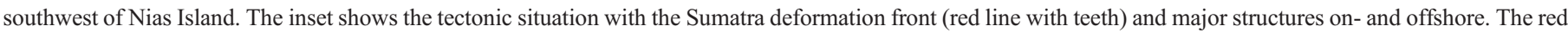

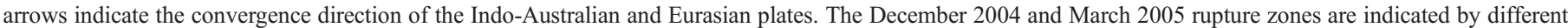

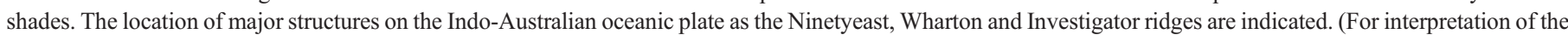
references to colour in this figure legend, the reader is referred to the web version of this article.) 
1996; McCarthy and Elders, 1997; Baroux et al., 1998; Sieh and Natawidjaja, 2000).

Off central Sumatra the convergent margin is mainly linear (Fig. 1), but farther north, in the region of the December 2004 and to the March 2005 ruptures, it becomes markedly arcuate along an area we here term the 're-entrant' (Fig. 1). Northwest of the re-entrant a change in morphology and structure of both the accretionary prism and the oceanic plate takes place. To the northwest, the Sumatra deformation front continues as a salient, with its apex offset $\sim 150 \mathrm{~km}$ to the west (Henstock et al., 2006; Fig. 1). The outboard slope of the accretionary prism is a pronounced feature with steep gradients of approximately $4^{\circ}$ to $8^{\circ}$ passing from $4500 \mathrm{~m}$ at the base to $1500 \mathrm{~m}$ at the top, where it forms an irregular plateau with water depths as shallow as $200 \mathrm{~m}$. There is no distinct outer arc high. The accretionary prism is $140 \mathrm{~km}$ wide with a structural trend generally parallel to the margin (Sibuet et al., 2007). At the re-entrant the architecture of the March 2005 rupture segment, is remarkably different to that in the north. The width of the accretionary prism decreases to $100 \mathrm{~km}$ (from the deformation front to the West Andaman fault), the wide plateau seen in the north disappears, and the more usual tapered form of an accretionary prism is present. There is an outer arc high on which are located a chain of small islands, of which Simeulue is the most northerly (Fig. 1). The region between Nias and Simeulue islands forms a broad northeast facing re-entrant.

\section{Methodology}

\subsection{Wide-angle/refraction seismics}

To obtain reliable velocity and structural information on the 122 deeper section of the accretionary wedge we acquired wide- 123 angle/refraction seismic data along two MCS profiles; BGR06- 124 208a and BGR06-135 (Fig. 1). Line BGR06-208a is situated 125 southwest of Simeulue Island. It is parallel to the trench and at a 126 mean distance of about $34 \pm 2 \mathrm{~km}$ from the toe of the 127 accretionary prism. Along this line, ten ocean-bottom hydro- 128 phones/seismometers were deployed with a mean separation of 129 $15 \mathrm{~km}$ (Fig. 1). 1763 shots were fired at intervals of about 130 $106 \mathrm{~m}$, resulting in a total length of profile of $186 \mathrm{~km}$. The wide- 131 angle seismic instruments recorded energy from an offset range 132 of at least -60 to $60 \mathrm{~km}$ (see Fig. 2 and Supplements 1 and 2 in 133 Appendix A). At all 10 stations we recorded well defined 134 refracted waves from within the sedimentary column $(\mathrm{Pg})$ of the 135 accretionary prism as well as clear wide-angle reflections of the 136 subducting oceanic crust $(\mathrm{PcP})$.

137

We constructed velocity-depth models by applying a tomo- 138 graphic method - tomo2d, (Korenaga et al., 2000) which inverts 139 traveltimes from both refracted and reflected waves. The result is 140 a velocity-depth-distribution and the position of the seismic 141 reflection from the subducted oceanic crust. The modelling 142 sequence for line BGR06-208a is as follows. For the compilation 143
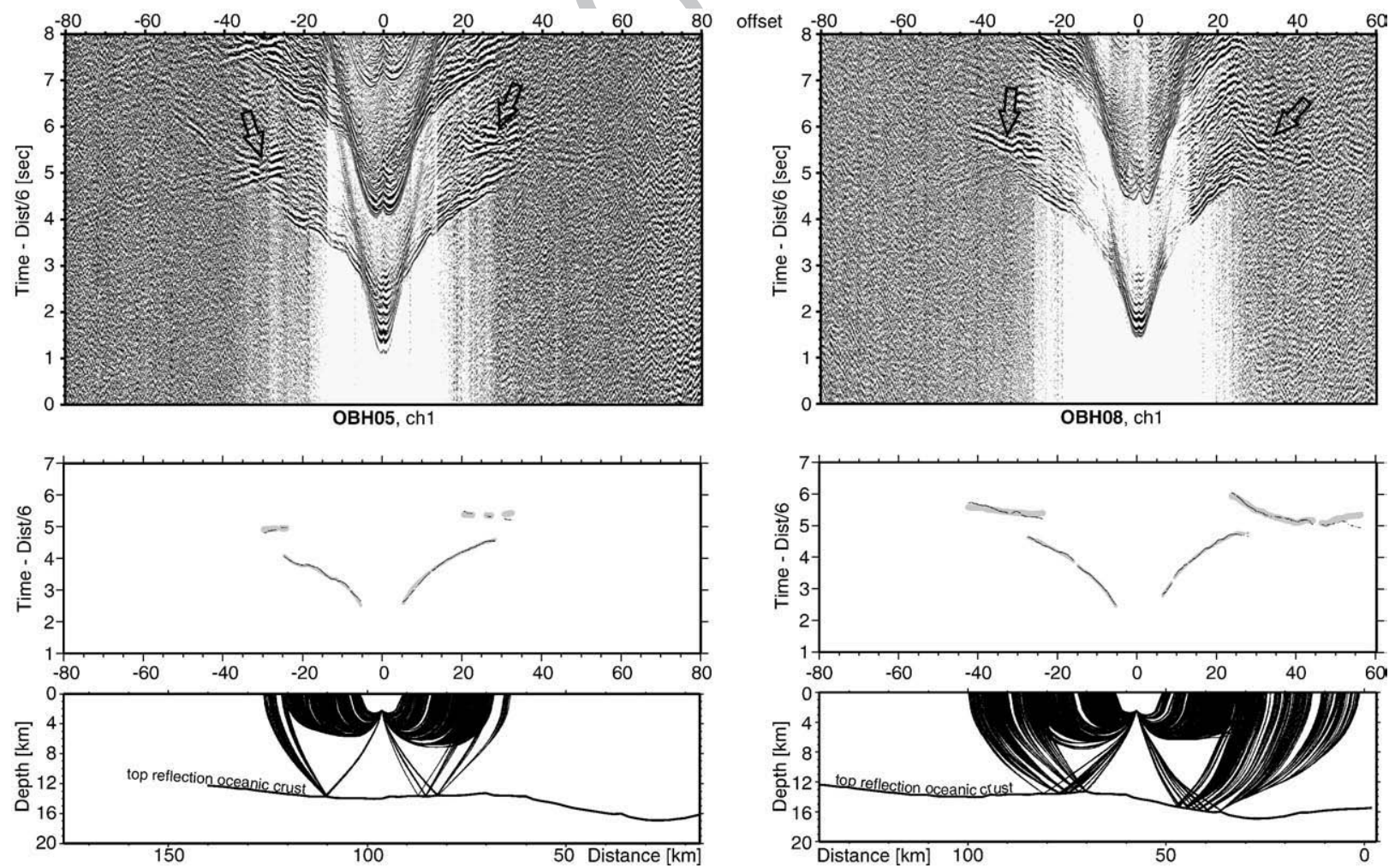

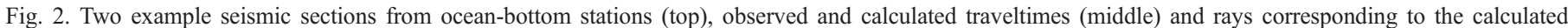

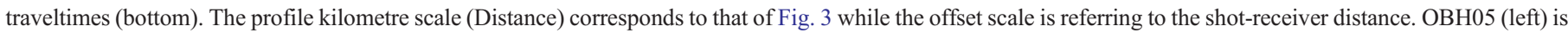

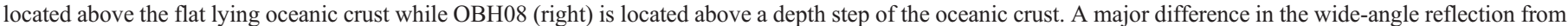

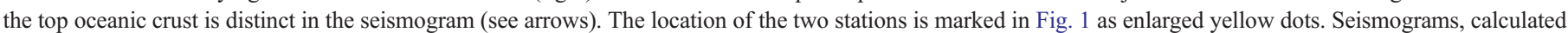
rays and traveltimes of all remaining eight stations are shown in Supplements 1 and 2 in Appendix A. 
of the starting model, we constrained the depth of the sea bottom with bathymetric data and used a 1-D velocity model with a constant gradient along the whole profile. The inversion was run in two steps. Firstly, inversion of the refracted waves through the sedimentary column provided a detailed velocity-depth model of the upper 6 to $8 \mathrm{~km}$ below sealevel. Between these depths the refracted waves, calculated as diving waves, reached their turning point and travelled back to the surface. Secondly, the traveltimes for reflected waves were calculated. The results provide both the seismic velocities between the well-constrained upper sedimentary section and the top of the oceanic crust at a depth of about 12 to $16 \mathrm{~km}$ together with the depth and profile of the oceanic crust. The top oceanic crust reflection is shown in Fig. 3 only for those regions where there is a good coverage of seismic rays, where the location of crust is well constrained.

The RMS misfit of the PcP phases is in the range of accuracy by which the traveltimes of the PcP phases could be picked. This misfit is less than $100 \mathrm{~ms}$ and gives an error in the depth determination of the oceanic crust reflector of less than $300 \mathrm{~m}$. The traveltimes of the Pg-phases are better resolved than those from the PcP, with a misfit of less than $40 \mathrm{~ms}$. From these results we consider the velocity model and depth to the oceanic crust to be well defined.

To confirm that the structures imaged are within the spatial resolution of the data, we performed checkerboard tests (Supplement 3 in Appendix A). The final velocity model, as obtained by the tomography, was tested with superimposed velocity anomalies of systematically decreasing size. A set of first arrival times and reflection phases together with corresponding ray paths were generated and formed the input for another tomography using the given source-receiver config- uration. If the perturbed model can be reproduced by the 175 tomography the size of the velocity anomalies are within the 176 vertical and horizontal resolution of the data. In this way we are 177 able to resolve velocity variations with a dimension of less than 178 $20 \times 8 \mathrm{~km}$. At the southeastern end of line BGR06-208a, the top 179 oceanic crust reflector is more than $3 \mathrm{~km}$ deeper than in the 180 centre of the profile (Fig. 3). The deeper location of the top 181 oceanic crust reflector was found over a distance of $40 \mathrm{~km}$, i.e. 182 twice the horizontal resolution of better than $20 \mathrm{~km}$. This proves 183 that the depth change identified is not a velocity artefact caused 184 by variations in the overlying sedimentary sequence. In fact 185 there is a uniform velocity structure in the sediments resting on 186 the subducting oceanic crust (Fig. 3). A constant depth for the 187 subducting oceanic crust would only be possible if there was a 188 distinct, and very large, low velocity zone (i.e. a very strong 189 velocity inversion) in the sediments above the section where we 190 identify the deeper oceanic crust (profile km 0-70). Such an 191 inversion is not possible.

192

To address the question of velocity-depth ambiguity, we 193 systematically varied the depth kernel weighting parameter 194 (Korenaga et al., 2000). The final velocity model shown in Fig. 3195 was calculated with a weighting parameter of unity, which 196 corresponds to equal weighting of velocity and depth nodes. 197 Decreasing the weighting parameter should lead to smaller depth 198 variations with larger velocity variations. However, even with an 199 implausible kernel weighting parameter as small as 0.1 (where the 200 velocity perturbations are very much greater than the perturbation of 201 the depth of the resulting reflector), the top of the oceanic crust in the 202 final model shows a depth change of $2 \mathrm{~km}$ towards the southeast. 203

The second wide-angle/refraction seismic line BGR06-135 204 runs perpendicular to the trench in SW-NE direction. The line 205

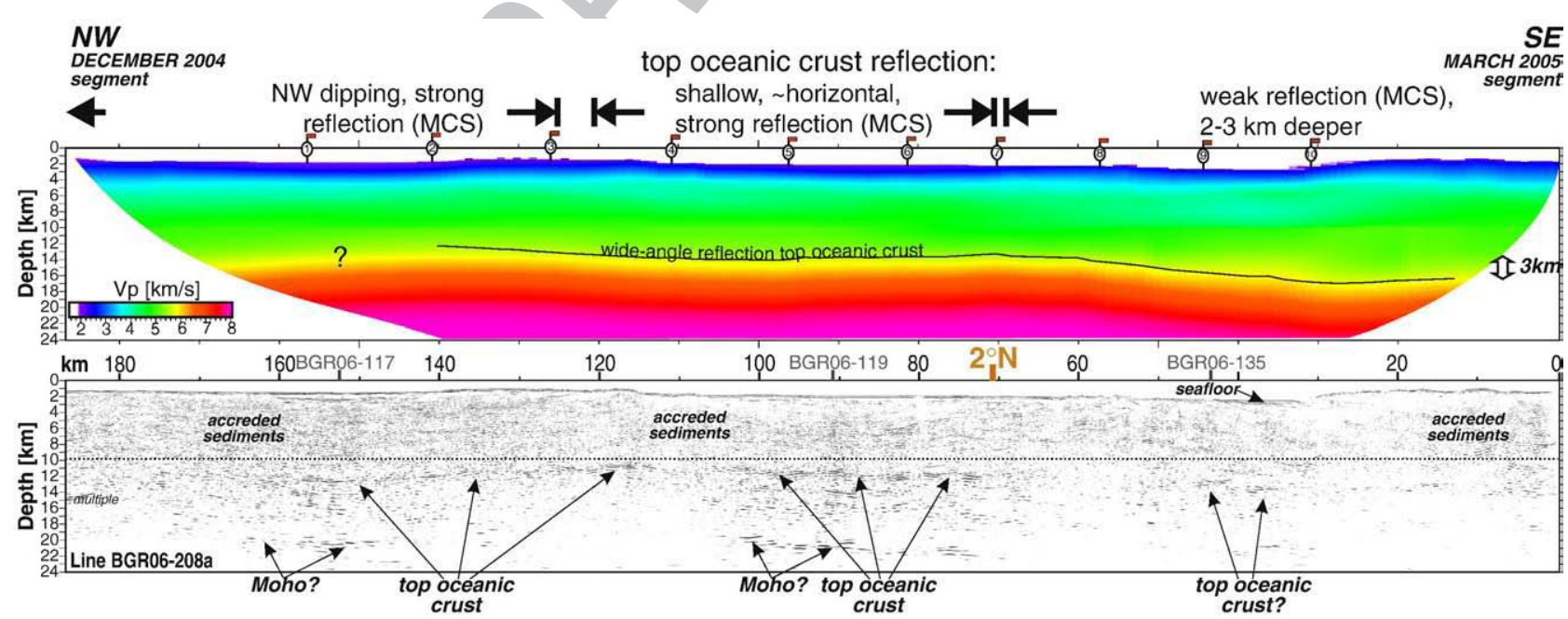

Fig. 3. Velocity-depth model (top) as derived from wide-angle/refraction seismic data and a prestack-depth migrated multichannel seismic line (bottom). Line BGR06208a runs margin parallel from the December 2004 segment across the segment boundary and extending SE-ward on the March 2005 segment. The location of the profile is indicated as thick red line in Fig. 1. Top: The inversion of the refracted waves from 10 ocean-bottom stations revealed a detailed velocity-depth model of the model's upper 6 to $8 \mathrm{~km}$. The traveltimes from reflected waves gave a detailed image of the seismic velocities down to the top of the oceanic crust at a depth of about 12 to $16 \mathrm{~km}$. We resolve the shape of the subducting oceanic plate along the profile (black line). In the SE (km 70 to 15 ) a distinct depth step of the subducting oceanic crust of more than $3 \mathrm{~km}$ is resolved. Bottom: The top reflection from the subducting oceanic crust is well imaged north of $2^{\circ} \mathrm{N}$ (profile km 160-70). It shows a dip to the NW from about $11 \mathrm{~km}$ depth to $12.5 \mathrm{~km}$ depth (profile $\mathrm{km} 120$ to 160). The reflection vanishes at the NW end of the line, where the initial velocity model for depth migration is poorly controlled. In the centre of the line (profile $\mathrm{km} \mathrm{70-120)} \mathrm{the} \mathrm{strong} \mathrm{reflective} \mathrm{top} \mathrm{of} \mathrm{the} \mathrm{oceanic} \mathrm{crust} \mathrm{lies} \mathrm{continuously} \mathrm{at} \mathrm{a} \mathrm{shallow} \mathrm{depth} \mathrm{of} 11$ to $12 \mathrm{~km}$. Southeast of $2^{\circ} \mathrm{N}$ (profile $\mathrm{km} 70-20$ ) only weak reflections are visible, which are located at 2 to $3 \mathrm{~km}$ greater depth. 
extends for $215 \mathrm{~km}$ from the oceanic plate to the Simeulue forearc basin. We recorded at a total of 31 ocean-bottom stations. Due to higher ships speed a shooting interval of $60 \mathrm{~s}$ resulted in an average shot spacing of about $120 \mathrm{~m}$. Here we only concentrate on the western, seaward, part of the line and use traveltimes of refracted waves from 13 stations to derive the velocity-depth model. PcP phases from 5 stations constrain velocities at greater depth down to the subducting oceanic crust.

We used a similar modelling procedure for this wide-angle/ refraction line as for line BGR06-208a. The resulting model provides seismic velocities for the trench fill and for the accretionary prism up to $60 \mathrm{~km}$ landward of the prism toe. The prism sediments have values of $4.0 \mathrm{~km} / \mathrm{s}$ at a depth of $3 \mathrm{~km}$ below seafloor, and reach a value of $5.5 \mathrm{~km} / \mathrm{s}$ at about $13 \mathrm{~km}$ below seafloor.

The results from the two wide-angle/refraction seismic lines provided an initial velocity model for the depth migration of the MCS lines (Section 3.2). Reflections beneath the top oceanic crust were recorded only occasionally in the wide-angle data. Thus the deeper parts of the velocity model are based mainly on extrapolation and, therefore, are tentative. In the MCS processing, in order to avoid any migration artefacts, we smoothed these velocity models in the crustal area with a vertical window of $3 \mathrm{~km}$. Thus there are minor differences between the wide-angle and the MCS velocity models.

\subsection{Multichannel reflection seismics (MCS)}

During our marine surveys over the 2004 and 2005 rupture zones a comprehensive dataset of some 9000 line kilometres of MCS data were acquired together with gravity and magnetics data. MCS data were acquired with a 240 channel, $3 \mathrm{~km}$ streamer (offset to near group: $150 \mathrm{~m}$; maximum offset: $3,137.5 \mathrm{~m}$ ), and a tuned airgun array comprising 16 airguns with a total capacity of $50.8 \mathrm{~L}$. Record length was $14 \mathrm{~s}$ with a sample interval of $2 \mathrm{~ms}$. A shot interval of $50 \mathrm{~m}$ resulted in a fold of 30 .

Processing of four MCS lines was performed up to full Kirchhoff prestack-depth migration and included the production and correction via MVA (migration velocity analysis) of a depth velocity model. After testing various combinations of processing parameters the following sequence was regarded as optimal. Prestack processing included geometry editing, deconvolution, true amplitude recovery, and filtering. Reduction of water-bottom multiples (a major challenge) was achieved by applying a parabolic radon filter and inner trace mutes. Stacking velocities, at an average distance interval of $3 \mathrm{~km}$, were determined for the reference poststack time migrated sections. The initial depth model was derived from the wide-angle/refraction seismic data along the lines BGR06-135 and BGR06-208a and from smoothed DMO velocities, adjusted and calibrated at the cross point with the refraction seismic line for lines BGR06-117 and -119. The upper parts of the velocity fields were iteratively improved via MVA until the migrated CRP gathers were flat. Quality control included a detailed evaluation of congruence between the poststack migrated sections and the time-converted prestack-depth migrated sections. Kirchhoff time migration, based on smoothed interval velocities derived from stacking 261 velocities, completed the poststack migration sequence for the 262 reference time migrated lines as well as for the additional lines 263 not depth migrated. Finally, time and space variant signal 264 filtering, time varying scaling and, along some sections, a 265 smooth fx-deconvolution completed the poststack processing 266 sequence.

\subsection{Bathymetry}

Swath bathymetry was acquired by the RV Sonne using a 269 $12 \mathrm{kHz}$ Simrad EM 120 and by the HMS Scott using $12 \mathrm{kHz} 270$ SASS-IV system (Henstock et al., 2006, Ladage et al., 2006). 271 The swath data was compiled and merged to provide a complete 272 map of the area off northern Sumatra (Figs. 1 and 6). 273 Interpretations of the swath bathymetry were integrated with 274 geodetic data to provide an overall picture of the structure of the 275 boundary between the 2004/2005 earthquakes located in the 276 vicinity of Simeulue Island.

\section{Results}

\subsection{Image of the plate interface}

The margin-parallel line BGR06-208a (Fig. 3) crosses the 280 boundary between the two earthquake ruptures of 2004 and 281 2005 in the vicinity of Simeulue Island. It lies $34 \pm 2 \mathrm{~km} 282$ landward of the deformation front. From the wide-angle seismic 283 data the velocity-depth model resolves the top oceanic crust 284 between line kilometres 15 and 140 (Fig. 3 - top). Only at the 285 margins is the ray coverage insufficient to image the reflection. 286 The oceanic crust is subhorizontal at a depth of about $12 \mathrm{~km} 287$ along the central part of the line. To the southeast over a 288 distance of $40 \mathrm{~km}$ the ocean crust depth gradually increases in 289 depth by more than $3 \mathrm{~km}$ (Fig. 3 - top; profile km 60-20; 290 south of $2^{\circ} \mathrm{N}$ ). Since the velocities of the overlying, accreted 291 sediments are uniform along the line the depth change is not an 292 artefact due to velocity pull-down.

The MCS data provides complementary insights into the finer 294 detail of the sedimentary prism, together with the crustal structure 295 than available from the wide-angle seismic data. Reflections of 296 the sedimentary prism and the underlying oceanic crust allow 297 refinement of the coarse interpretations based on the refraction 298 results. Conversely, the refraction models provide a constraint on 299 interpretations of the MCS (Mooney and Brocher, 1987).

On the MCS data, the profile of the subducting oceanic crust is 301 seen to be broadly similar to that on the wide-angle seismics 302 (Fig. 3 - bottom). However, there are distinct regions of strongly 303 reflective oceanic crust alternating with regions of weaker 304 reflections. In the centre of the line (Fig. 3 - bottom; profile km 305 70-120) the strongly reflective top of the oceanic crust lies 306 continuously at a shallow depth of 11 to $12 \mathrm{~km}$. To the northwest the 307 strongly reflective oceanic crust dips slightly from about $11 \mathrm{~km}$ to 308 $12.5 \mathrm{~km}$ depth (Fig. 3 - bottom; profile km 120 to 160). The 309 oceanic crust reflection is not imaged at the northwestern end of the 310 line where the initial velocity model for depth migration is poorly 311 controlled. 
NW $40^{\text {BGRO6-118 }}{ }^{\text {Il }}$ deep sea plain $^{\text {d }}$

deformation
front

DECEMBE

segment

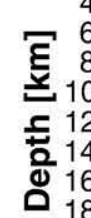

4 .

20 BGRo6-

BGR06-12040 BGR06-208a
I I

60

km

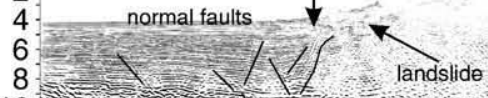

8
10

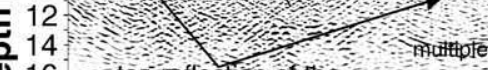

16 top reflection of the

20 - inultipte= $=$

22. Line BGR06-117
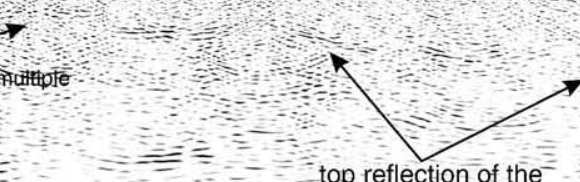

top reflection of the

A

4

relative panel alignment: profile BGR06-208a
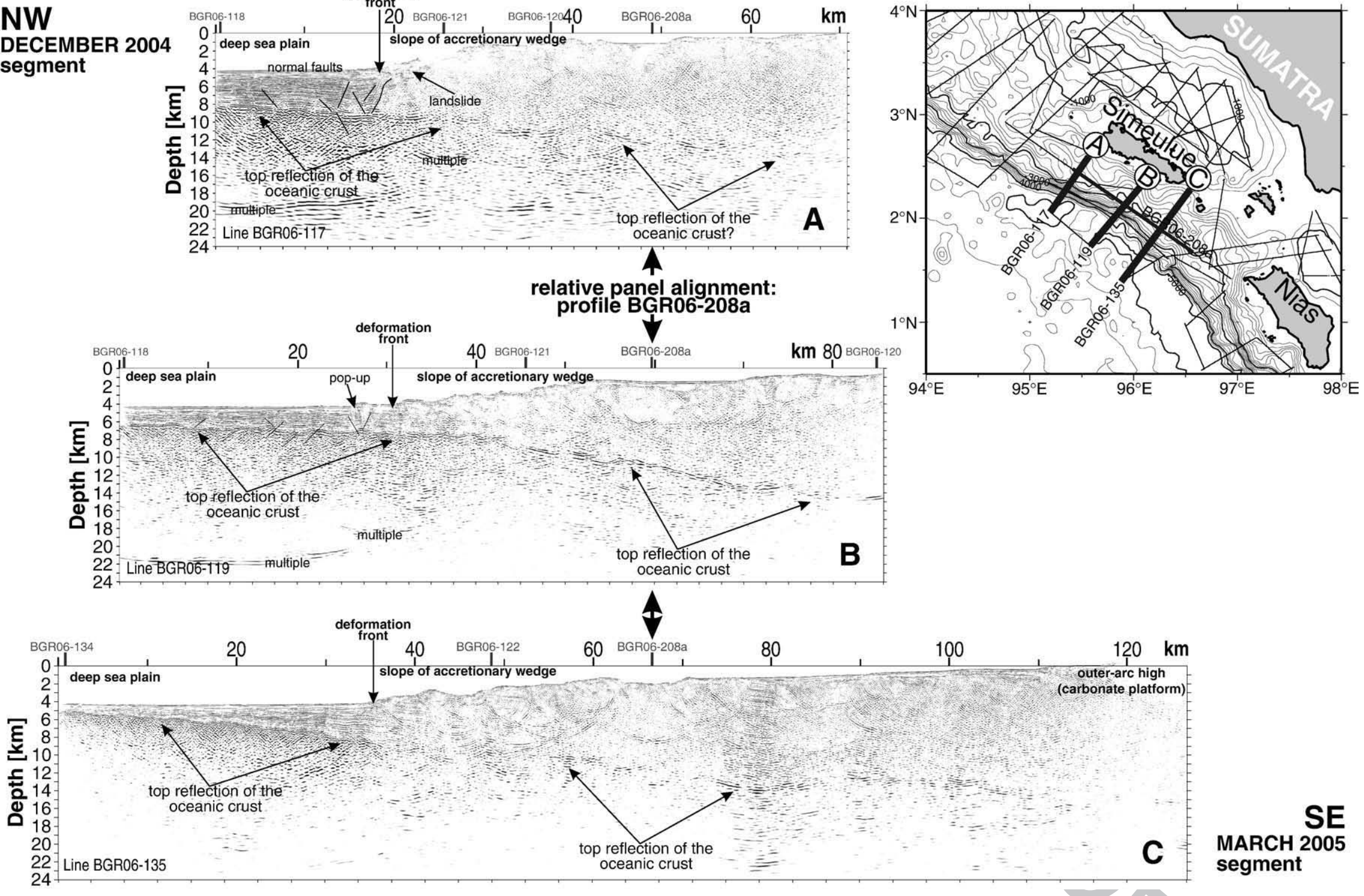

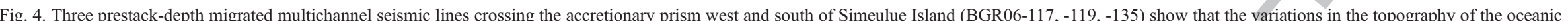

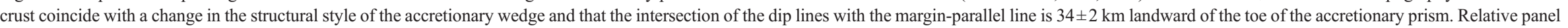

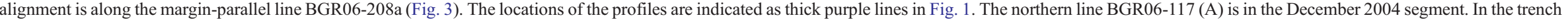

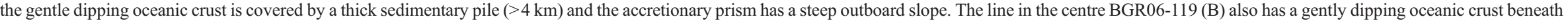

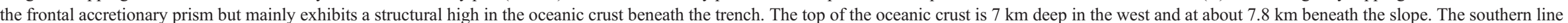

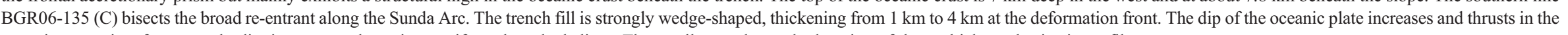
accretionary prism form steeply dipping, seaward verging, antiformal stacked slices. The small map shows the location of the multichannel seismic profiles. 
Southeast of $2^{\circ} \mathrm{N}$ (Fig. 3 - bottom; profile $\mathrm{km} 70$ ) there are no MCS reflections from the top of the oceanic crust for some $20 \mathrm{~km}$. This absence of reflections is where, on the wide-angle seismic data, there is a gradual increase in depth of the oceanic crust. Further south at km 45 on the MCS line, the oceanic crust reappears as a weak, discontinuous reflection about $2 \mathrm{~km}$ deeper than in the central part of profile. The change in reflectivity is not due to any change in the character of the overlying sediments because these can be traced across this region.

In the region traversed by the seismic line the deformation front is slightly curved because it is located in the broad reentrant region between Nias and Simeulue islands. However, the change in the depth of the oceanic crust cannot be attributed to an oblique relationship between the orientation of the seismic line and the deformation front. Even if there was some limited obliquity between the orientation of the seismic line and the dip of the slab, given an average dip of the oceanic crust of about $5^{\circ}$ an offstrike distance of $2 \mathrm{~km}$ either up or down the slab would result in a depth change of the top oceanic crust of less than $200 \mathrm{~m}$.

From both seismic datasets we can identify an increase in depth along the strike of the oceanic crust of between $2 \mathrm{~km}$ (MCS) and $3 \mathrm{~km}$ (wide-angle data). Due to the MCS streamer length of $3000 \mathrm{~m}$, absolute oceanic crust depth values are probably better resolved from the wide-angle seismic data. The observed variations in slab depth are due to a prominent structural relief in the lower plate. The location of the change in slab depth coincides with the segment boundary outlined by the aftershock distribution (Ammon, 2006). The depth change is limited to a $40 \mathrm{~km}$ wide region of the lower plate at approximately $2^{\circ} \mathrm{N}$ and $96^{\circ} \mathrm{E}$.

\subsection{Structural architecture and domains along the margin}

Southwest of Simeulue, towards the trench, we acquired MCS data along three dip lines that cross the accretionary prism. These lines are shown in Fig. 4 arranged relatively to the line-ties with BGR06-208a.

Profile BGR06-117 (Fig. 4A) is located in the southern region of the December 2004 earthquake rupture. The line extends for some $72 \mathrm{~km}$ across the trench and accretionary prism at the northwestern tip of the re-entrant. Along the line the trench fill is more than $4 \mathrm{~km}(3.4 \mathrm{~s}$ TWT $)$ thick and at the seabed completely levels out the oceanic crust relief. The fill consists of continuous parallel to sub-parallel reflections cut by palaeochannels. The seismic character is typical of turbidite facies. A series of conjugate normal faults cuts the entire trench fill. The oceanic crust can be traced beneath the frontal accretionary prism. It dips at about $4^{\circ}$. At the tie-point with line BGR06208a, some $34 \mathrm{~km}$ northeast of the toe of the accretionary prism, the oceanic crust is at a depth of $\sim 12.5 \mathrm{~km}$. Almost all the sedimentary cover on the incoming plate is offscraped and deformed at the prism toe. Thus almost all incoming sediment is accreted to the frontal prism. Within $12 \mathrm{~km}$ of the prism toe there is a doubling of the sediment thickness resting on the subducting plate. This increase in sediment thickness results in an extraordinarily steep prism slope of $15^{\circ}$. The increase in thickness is accompanied by frontal collapse structures.
MCS line BGR06-119 is located $60 \mathrm{~km}$ to the SSE of 368 BGR06-117, just offshore and perpendicular to Simeulue 369 Island. At the southwest end of the line, the top of the oceanic 370 crust is at $7 \mathrm{~km}$ depth. Beneath the prism toe this depth increases 371 to about $8 \mathrm{~km}$ (Fig. 4B). Oceanic crust depths are considerably 372 shallower $(\sim 2 \mathrm{~km})$ than on line BGR06-117 (Fig. 4A). Along 373 line BGR06-119 the oceanic crust entering the subduction zone 374 shows a similar normal fault pattern to that on line BGR06-117. 375 However, the trench fill is only $2 \mathrm{~km}$ thick and slightly more 376 wedge-shaped as it passes towards the accretionary prism. 377 Normal faults penetrate the trench fill but heal upwards. Above 378 a $500 \mathrm{~m}$ elevated graben shoulder in the oceanic crust a popup 379 structure delineates the youngest outboard deformation. Again, 380 there is frontal accretion of almost the whole trench fill at the 381 prism toe, thus the incoming sediments are basally detached. 382 However, the resulting frontal toe of the accretionary wedge is 383 broader than further north and not as steeply dipping. The 384 oceanic crust dips gently beneath the trench at the toe but the dip 385 increases beneath the slope. About $32 \mathrm{~km}$ from the toe of the 386 prism it reaches a depth of $\sim 11.5 \mathrm{~km}$ at the line-tie with line 387 BGR06-208a. Here the oceanic crust dips of $\sim 6^{\circ}$.

MCS line BGR06-135 runs from SW to NE from the oceanic 389 plate to the eastern part of the Simeulue Basin (Fig. 4C). It is 390 located in the northern region of the March 2005 rupture. The 391 profile lies at the apex of the broad re-entrant located off of 392 Simeulue and Nias Island. The trench fill is strongly wedge- 393 shaped, thickening from $1 \mathrm{~km}$ in the southwest to $4 \mathrm{~km}$ at the 394 deformation front. Again, the trench fill and oceanic crust are 395 normally faulted. In the lower section of the accretionary prism 396 there is imbricate thrusting of the accreted sediment similar in 397 style to that on line BGR06-119 and also seen further south 398 (Schlüter et al., 2002; Susilohadi et al., 2005). The oceanic crust 399 reflection is discontinuous but can be traced for more than 400 $70 \mathrm{~km}$ to the northeast of the deformation front (Fig. 4C). There 401 is an increase in depth of the oceanic crust from $9 \mathrm{~km}$ at the 402 deformation front to $\sim 13 \mathrm{~km}$ at the line-tie with line BGR06- 403 208a. This corresponds to a slab dip of $6.7^{\circ}$ beneath the frontal 404 accretionary prism.

Comparing the three cross-profiles we establish an increase 406 in slab dip from the north $\left(4^{\circ}\right)$ to the south $\left(6.7^{\circ}\right)$ beneath the 407 frontal prism slope. This trend is accompanied by decreasing 408 seabed slope angle of the frontal accretionary prism. Large 409 seabed slope angles in the north coincide with the accretion of a 410 thick sedimentary column whereas the thinner incoming 411 sedimentary pile south of Simeulue Island corresponds with 412 lower slope angles.

\section{Discussion}

\subsection{Origin of slab relief}

The simplest hypothesis to explain the shallow depth oceanic 416 slab north of $2^{\circ}$ identified on our data, would be a broad rise on 417 the lower plate created as the Indo-Australian Plate is subducted 418 beneath the $300 \mathrm{~km}$ long re-entrant. The re-entrant (Fig. 1) 419 extends as far south as Nias Island and interaction with the over- 420 riding Eurasian plate along this feature would result in a rise in 421 
the oceanic plate with the apex approximately located midway between Nias and Simeulue islands. However, there are several inconsistencies in this explanation that lead us to consider a different source to be more likely. Our seismic profiles show that the shallowest slab reflections are in the northern third of the re-entrant, offshore of Simeulue. The shallow slab section here is only $60 \mathrm{~km}$ long and the dips at either end resolved by our data are too steep to be explained by a rise of longer 429 (300 km) wavelength. The opposing dip directions at the ends 430 of the slab suggest a smaller, more local, source. Moreover, on 431 line BGR06-135, located at the apex of the re-entrant, there is an 432 oceanic crust that is more steeply landward dipping (Fig. 4C) 433 than to the north (Figs. 4A and B). This would not be expected if 434 the shallow slab was formed by a broad rise on oceanic crust 435
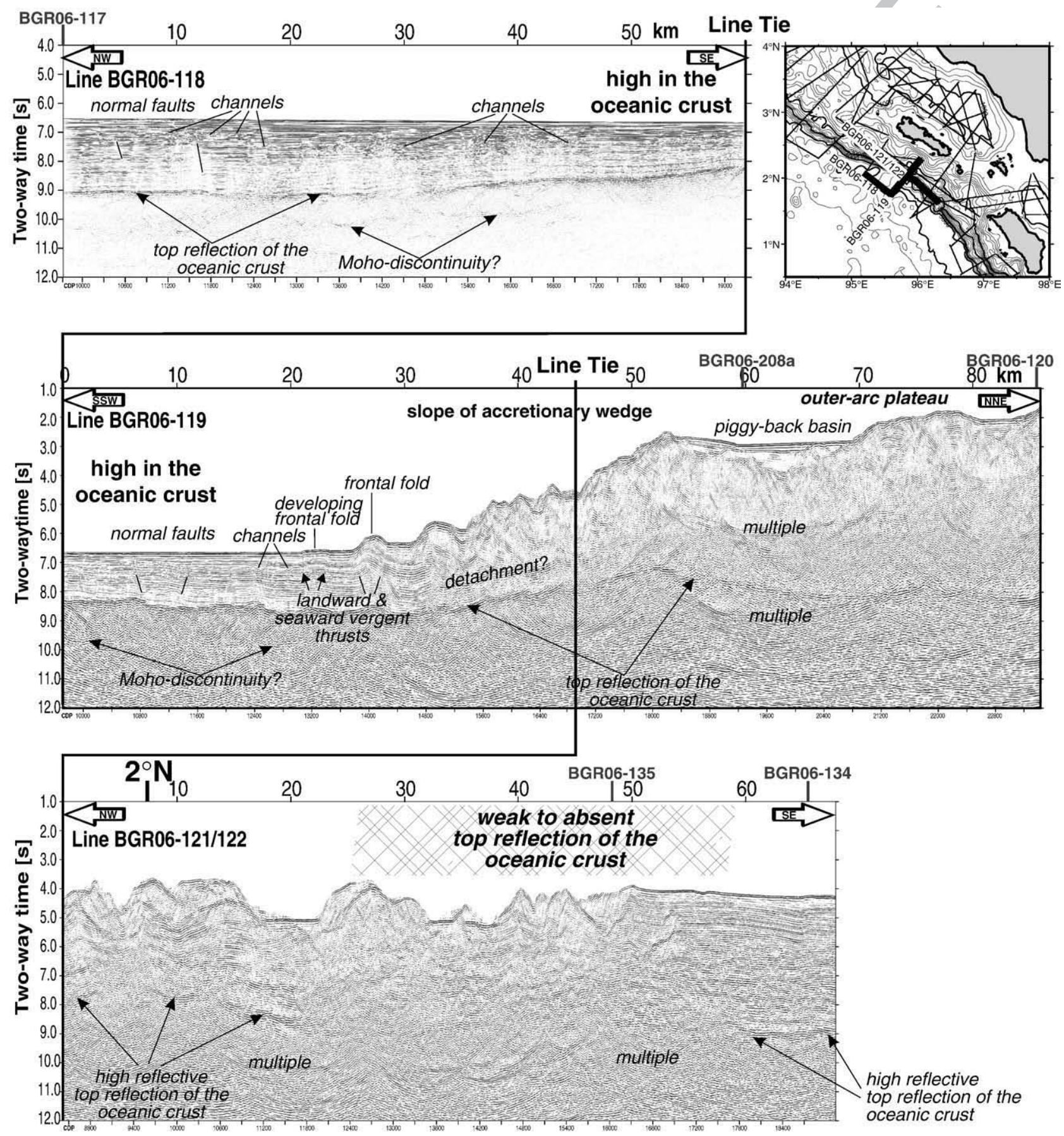

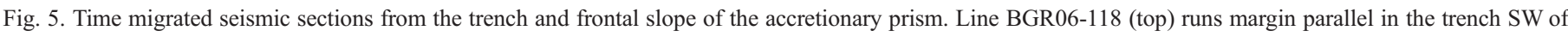

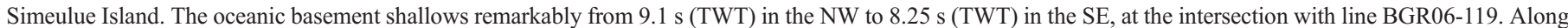

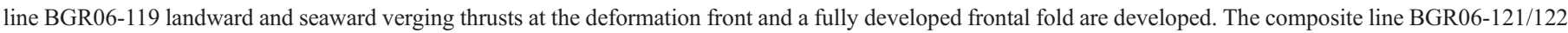

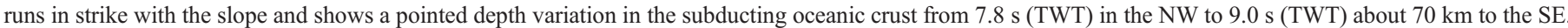

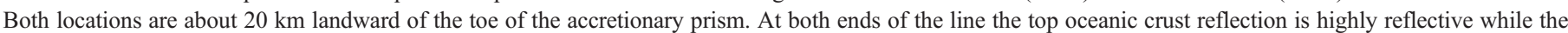
reflection becomes weak to absent in the centre (profile km 26-58). 
subducting along the re-entrant. We conclude, therefore, that the narrow width and steep marginal dips of the shallow slab reflection cannot be explained by a broad rise on the slab that has formed by broad-scale subduction beneath the re-entrant. Rather, the data support the subduction of an elongated, narrow high on the subducting plate.

For the origin of the narrow high we refer to the IndoAustralian Plate offshore of Sumatra, the structure of which is reasonably well established (Cande et al., 1989; Deplus et al., 1998; Milsom, 2005; Delescluse and Chamot-Rooke, 2007). Dominant structures on the plate are $\mathrm{E}-\mathrm{W}$ trending extinct spreading ridges, or $\mathrm{N}-\mathrm{S}$ trending fracture zones. However, on the oceanic plate off Simeulue Island along strike from the feature we identify, neither spreading ridges nor fracture zones are evident on our high-resolution bathymetry nor on satellite altimetry (Smith and Sandwell, 1997). Further south, where the sedimentary cover thins, several fracture zones are imaged on gravity and magnetic data and the satellite altimetry (Smith and Sandwell, 1997). Morphologically, these fracture zones appear as complex structures of alternating topographic highs and lows (Ladage et al., 2006). Their width $(30-50 \mathrm{~km})$ and relief $(\sim 500-$ $2000 \mathrm{~m}$ ) are of same order of magnitude as the rise observed in our seismic data south of Simeulue. The Investigator Fracture Zone, which trends approximately north-south at $98^{\circ} \mathrm{E}$, has an estimated elevation of up to $2000 \mathrm{~m}$ (Milsom, 2005).

North of the re-entrant, at $93.2^{\circ} \mathrm{E}$ and $93.6^{\circ} \mathrm{E}$, Sibuet et al. (2007) propose that north-south oriented tectonic lineaments on the incoming plate are related to palaeo-fracture zones. These authors suggest that these fracture zones have been subducted and are influencing upper plate deformation, being reactivated with left-lateral slip during the December 2004 mainshock. Another fracture zone, further south of those identified by Sibuet et al. (2007), can also be mapped from magnetic anomaly patterns (Cande et al., 1989; Barckhausen, 2006) and traced into the area off Simeulue. A fracture zone at this location was also inferred by Newcomb and McCann (1987). It projects almost exactly onto the location of the elevated oceanic crust we identify along line BGR06-208a (Fig. 3). In conclusion, we suggest that it is this fracture zone, now deeply buried beneath trench sediment, that is the source of the shallow flat slab we identify on line BGR06-208a.

\subsection{Orientation of shallow slab/fracture zone}

The question remains, what is the orientation of the shallow slab, and does this support a fracture zone origin? Fig. 3 shows a slightly NW dipping oceanic crust reflection in the NW part of line BGR06-208a. As this is at the edge of the velocity-depth model, the increase in depth of the oceanic crust to the NW is not well constrained. However, in this region, but further to the southwest on line BGR06-118 (Fig. 5 - top) we observe a similar depth trend in the oceanic crust seaward of the accretionary prism. Seismic line BGR06-118 is about $60 \mathrm{~km}$ $\mathrm{SW}$ of the prism toe and oriented parallel to the trench as well as to line BGR06-208a. The top of the oceanic crust is well imaged and dips to the NW, as on line BGR06-208a. It shallows over a distance of $30 \mathrm{~km}$ from $9.1 \mathrm{~s}$ (TWT) in the NW to $8.25 \mathrm{~s}$ (TWT) in the SE (Fig. 5 - top) where it intersects line BGR06-119 491 (Fig. 5 - middle). Its relief at seabed is masked by the drape of 492 the trench fill sediments. A line connecting the relief in the 493 oceanic crust identified along line BGR06-118 with the increase 494 in depth of the oceanic crust to the NW along the margin- 495 parallel line BGR06-208a would strike NNE.

496

Turning to composite line BGR06-121/122 (Fig. 5-497 bottom). This line is margin parallel and located between the toe 498 of the accretionary prism and line BGR06-208a. At the cross tie 499 between lines BGR06-119 and BGR06-121/122 the oceanic 500 crust is at a depth of $7.8 \mathrm{~s}$ (TWT). At the southern end of 501 BGR06-121/122, about $70 \mathrm{~km}$ to the south, it is at $9.0 \mathrm{~s}$ (TWT) 502 (Fig. 5, bottom). The sedimentary thickness is $4 \mathrm{~s}$ (TWT) at the 503 northwestern end of the line whereas it is up to $5 \mathrm{~s}$ (TWT) in the 504 southeast. Although the seabed relief is more irregular in the 505 northwest (smoother in the southeast) the water depths on 506 average remain the same along the line. However, although the 507 top oceanic crust reflection is clearly imaged at both ends of the 508 line, between $\mathrm{km} 25$ and 58 it disappears. Both locations are 509 about $20 \mathrm{~km}$ landward of the toe of the accretionary prism. In 510 the SE part of the profile the back limb of an anticline is imaged 511 showing smooth topography and subhorizontal strata. It is 512 therefore surprising that the highly reflective top oceanic crust 513 reflection becomes weak to absent northeast of $\mathrm{km} \mathrm{58,} \mathrm{where} \mathrm{it} 514$ still underlies the subhorizontal strata (Fig. 5 - bottom). $\quad 515$

We consider the absence of the reflection to be attributable to 516 the same cause as on line BGR06-208a. Allowing for the 517 difference in sediment thickness along line BGR06-121/122, 518 that would result in a velocity pull-up in the southeast, in the 519 southeast the oceanic crust reflection is about $2.5 \mathrm{~km}$ deeper 520 than in the northwest. A line connecting the locations of weak 521 oceanic crust reflections as well as the increase in depth from 522 composite line BGR06-121/122 and line BGR06-208a would 523 strike NNE towards Simeulue (Fig. 6 - top).

\subsection{Links between lower and upper plates}

GPS measurements on Simeulue Island (Subarya et al., 526 2006, Briggs et al., 2006) reveal vertical uplift in the north 527 during the earthquake of December 2004 and uplift in the south 528 of the island during the March 2005 event. The differential 529 uplift defines a saddle in the middle of the island. It is taken as 530 evidence for a major basement structure that may control 531 rupture termination and a segment boundary (Briggs et al., 532 2006). Projecting the trend of the slab rise (fracture zone) on our 533 seismic data onto Simeulue Island reveals a close alignment 534 with the saddle identified by Briggs et al. (2006), with a trend of 535 NNE-SSW $\left(\sim \mathrm{N} 10^{\circ}\right)$. The proposed NNE trend identified on 536 our data also projects onto the nucleation point of the December 537 2004 earthquake (Fig. 6 - top). Consideration of the uplift on 538 Simeulue in the context of our interpretations of an increase in 539 depth of the oceanic crust seen in our wide-angle/refraction and 540 MCS data may reflect a common cause.

Relative plate convergence between the Indo-Australian and 542 Eurasian plates is parallel to the general trend of the strike of the 543 extinct fracture zones (Subarya et al., 2006; Simons et al., 544 2007). Assuming a constant plate motion vector for the past 5545 


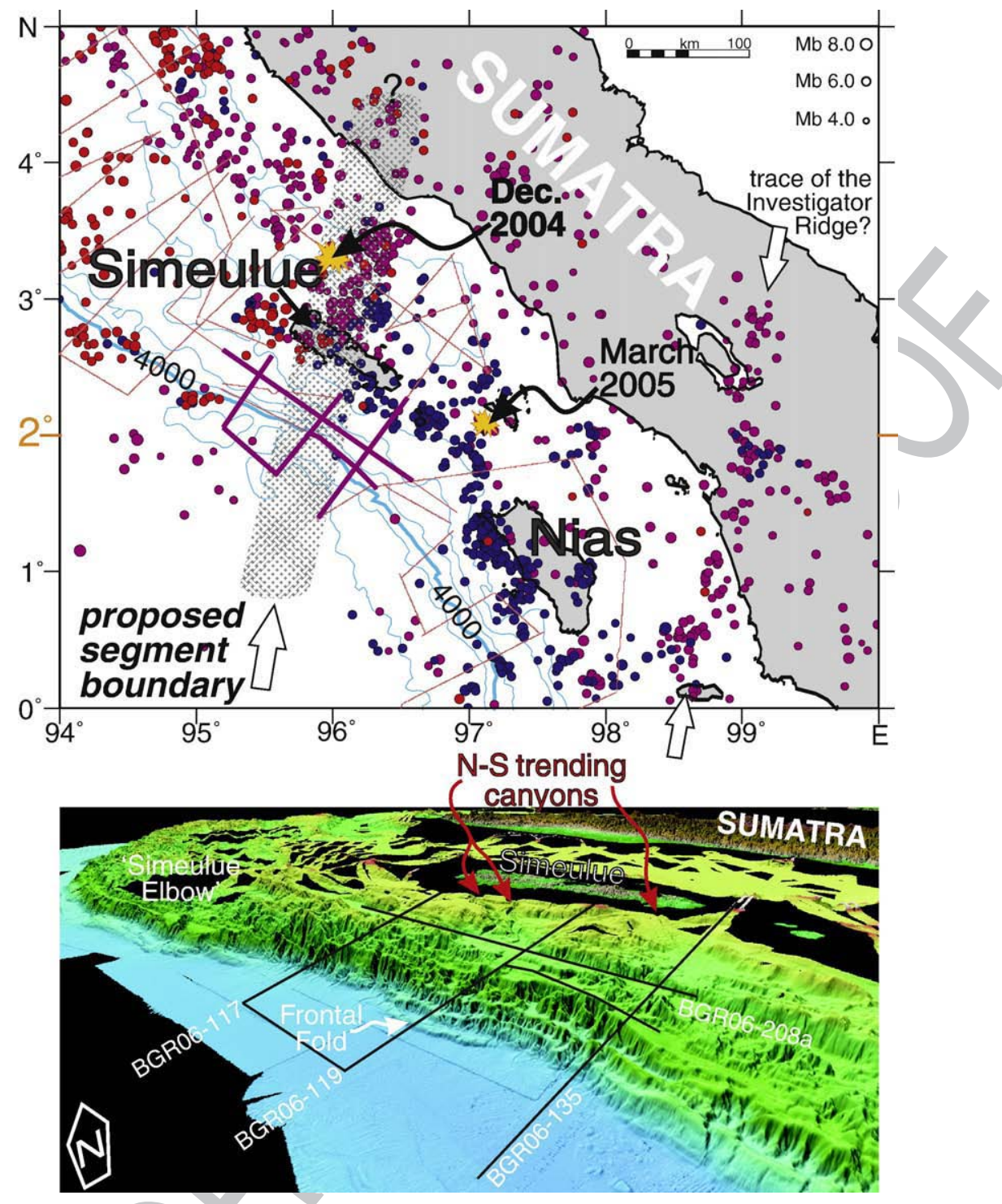

Fig. 6. NNE extent of the proposed segment boundary as revealed by the seismic data (upper panel) and enlarged bathymetric map of the broad re-entrant south of Simeulue Island (lower panel). Top: Seismicity before December, 26th 2004 is shown in purple, aftershocks of the 2004 mainshock in red, and aftershocks of the 2005 mainshock in blue (Engdahl et al., 2007). The distribution of the earthquakes is not in contradiction to the proposed trend of the segment boundary. The likely trace of the subducting Investigator Ridge indicated by an elongated cluster of epicentres is also marked. Purple lines mark the location of the reflection seismic lines shown in Figs. 3, 4 and 5. Bottom: Swath bathymetry shown with a vertical exaggeration of 2. Location of the seismic lines discussed in the text is indicated. The slope off Simeulue Island is cut by canyons striking $\mathrm{N}-\mathrm{S}$, probably linked to structures of the subducting plate, most likely a fracture zone. (For interpretation of the references to colour in this figure legend, the reader is referred to the web version of this article.)

million years (Hall, 2002; Delescluse and Chamot-Rooke, 2007) the location of the collision between an N-S oriented fracture zone and the convergent margin has remained stationary. This coincidence between the relative plate vector and the strike of the extinct fracture zones results in the deformation of the upper plate during subduction of the fracture zone ridge remaining stationary also. It is surmised that such deformation over an extended time period would produce a significant structural change in the over-riding plate, such as a major tectonic boundary. There appears to be no large-scale evidence of this structural change on Simeulue Island, nor on the accretionary prism. However, offshore of Simeulue Island, to the southwest, there are several submarine canyons. These canyons are aligned with tectonic lineaments striking $\mathrm{N}-\mathrm{S}$
(Fig. 6 - bottom; Ladage et al., 2006). They may be an 560 expression of local tectonic deformation due to the deformation 561 identified on our seismic data and on Simeulue. Their presence 562 may reflect a pervasive structural control by the oceanic plate on 563 upper plate deformation. Therefore, we propose that off Simeulue 564 the structural relief of a subducting extinct fracture zone entering 565 the accretionary wedge at about $2^{\circ} \mathrm{N}$ contributes to or is a major 566 control on segmentation of the forearc. DeShon et al. (2005) 567 suggest that the southern boundary of the Andaman microplate is 568 located in the vicinity of Simeulue Island. Although the evidence 569 is equivocal, it may also be that this boundary was initiated by 570 subduction of the fracture zone.

However, the evidence suggests that NNE-SSW oriented 572 fracture zones on the oceanic plate are influencing deformation 573 
on the over-riding plate, imparting structures that are oriented in the same direction. Previously, the orientation of the segment boundary was inferred to be orthogonal to the plate boundary (Newcomb and McCann, 1987; Ammon et al., 2005; Bilham, 2005). In this regard the aftershock distribution is ambiguous but, however, in terms of orientation of the segment boundary, does not discount an alternative trend of NNE-SSW (Fig. 6).

\subsection{Simeulue segment boundary}

Fracture zones and other structural discontinuities on the downgoing plate are first-order candidates for the initiation of segmentation and earthquake rupture termination between the 2004 and 2005 earthquakes (e.g. Subarya et al., 2006). Our data lends support to this interpretation. The shallow slab we identify is $60 \mathrm{~km}$ wide and elevated for about $1 \mathrm{~km}$ towards the NW and for some $3 \mathrm{~km}$ towards the SE. As an extinct fracture zone, it is comparable in width and height, to the Investigator Ridge, another $\mathrm{N}-\mathrm{S}$ trending fracture zone on the Indo-Australian Plate. Located further south, the Investigator Ridge, where it collides with the accretionary wedge at $89^{\circ} \mathrm{E}, 2.5^{\circ} \mathrm{S}$, has a width of $30-50 \mathrm{~km}$ and an elevation of about $1 \mathrm{~km}$. Perhaps significantly, the collision zone of this feature correlates with the boundary between the 1797 and 1833 great earthquakes (northern end) and the 1861 great earthquake (southern end) offshore of southern Sumatra (Fauzi et al., 1996; Sieh and Natawidjaja, 2000; Rivera et al., 2002).

A particular feature of the Simeulue fracture zone that may contribute to its effect on margin segmentation is its size and asymmetry. The relief of the fracture zone is far greater than that of the other prominent fracture zones and ridges (including the Investigator Ridge) on the Indo-Australian plate. The eastern flank of the ridge off Simeulue is at $3 \mathrm{~km}$ high much higher than the western flank. This height is twice that of the Investigator Ridge.

This relief across a fracture zone could be a function of the juxtaposition of crust of significantly different ages. The general age of the oceanic crust, however, is Eocene and, assuming symmetrical spreading, there is an age difference of $\sim 2 \mathrm{Ma}$ (Cande et al., 1989). The resulting seafloor depth difference will, therefore, be only of the order of 100-200 m, a difference that cannot account for the overall relief observed across the fracture zone.

Alternatively a fault or tear at the eastern flank of the proposed fracture zone could explain the depth difference of $3 \mathrm{~km}$ we observe. Modelling the wide-angle seismic data reveals that the top of the subducting oceanic crust gradually increases in depth (Fig. 3 - top). However, the spatial resolution is limited due to the layout of the wide-angle seismic experiment and the modelling algorithm used. An abrupt depth change like a steep ramp or tear would also be resolved as smooth transition with this acquisition configuration.

The interpretation of this feature as a fault or tear is supported by the MCS data. These show weak and discontinuous reflections on both margin-parallel lines BGR06-208a and BGR06-122 east of the topographic high of the proposed fracture zone (Figs. 3 and 5). This reflection character would not be expected if it were merely a gradual change in slab depth.
Rather, it favours a faulted and dissected eastern flank of the 629 Simeulue fracture zone.

The N-S to NNE-SSW striking fracture zones on the Indo- 631 Australian plate between the Ninetyeast ridge and Sumatra are 632 activated and reactivated as left-lateral strike-slip faults (Deplus et 633 al., 1998). Close to the trench these are additionally reactivated as 634 normal faults caused by flexural bending of the oceanic plate as it 635 descends into the subduction zone (Schauer et al., 2006; 636 Graindorge et al., 2007). The fracture zone off of Simeulue we 637 consider to be similarly reactivated and dip-slip movements along 638 the eastern flank have resulted in the observed step in the oceanic 639 slab. Faulting along the eastern edge of this fracture zone possibly 640 penetrates the entire oceanic slab. The result could be a tear in the 641 subducting plate as slab dip increases beneath the accretionary 642 prism. This may be an answer, as to why the Simeulue fracture 643 zone is such a prominent barrier to rupture propagation.

\section{Conclusions}

Interpretation of a suite of marine geophysical data including 646 wide-angle seismic and multichannel reflection seismic reveals a 647 ridge on the subducting oceanic crust, entering the accretionary 648 wedge off Sumatra located at $95.6^{\circ} \mathrm{E}, 2^{\circ} \mathrm{N}$. The western flank of 649 the ridge is about $1 \mathrm{~km}$ high whereas the eastern flank is up to 650 $3 \mathrm{~km}$. Trench sediments up to $5 \mathrm{~km}$ in thickness mask the 651 topographic relief of the oceanic crust so that the ridge is not 652 visible on the bathymetric data. The ridge is about $60 \mathrm{~km}$ wide and 653 strikes in NNE-SSW direction. It extends beneath the accre- 654 tionary wedge and likely also beneath Simeulue Island.

655

The projection of the ridge beneath the accretionary wedge 656 and further under the forearc basins plots onto the common 657 segment boundary of the 2004 and 2005 mainshocks. This 658 relationship implies a structural control of the downgoing ridge 659 on the segment boundary between the huge ruptures of the 660 December 2004 and the March 2005 earthquakes. The trend of 661 the ridge is parallel to fracture zones on the Indo-Australian 662 plate and we consider such a fracture zone, buried by thick 663 sediments as likely origin of the ridge.

The ridge on the oceanic crust contributes to or is a major 665 control on the initiation of the segment boundary. The step in 666 the slab across the eastern flank of the proposed ridge/fracture 667 zone could be the result of either a gradual, oblique ramp or a 668 shallow slab tear. However, the gradual depth change of $3 \mathrm{~km}$ as 669 derived by wide-angle/refraction seismic data coincides with a 670 significant change in the reflectivity of the oceanic crust 671 reflection in the multichannel seismic data. We consider that this 672 may reflect a dissected and faulted subducting oceanic crust. 673 Dip-slip movements along the eastern flank of the subducting 674 fracture zone beneath Simeulue may be considered as 675 intensification factor in terms of rupture propagation barrier. $\quad 676$

\section{Acknowledgements}

We are indebted to the Government of Indonesia (BPPT) as 678 Indonesian partner providing the permission for the investiga- 679 tions in its territorial water. We thank ship's masters and their 680 crew for operating RV Sonne. We are grateful to Petrologic 681 
Geophysical Service Gmbh, Hannover, Germany for providing support in performing the prestack-depth migration. The SASS multibeam data was acquired by HMS SCOTT, a UK Royal Navy Survey Vessel during Marine Scientific Research coordinated by the Joint Environment Directorate of Defence Intelligence, and the data was processed by the United Kingdom Hydrographic Office. David Tappin publishes with the permission of the Executive Director of the British Geological Survey. We thank Robert Engdahl for providing hypocentre data. Helpful comments by two anonymous reviewers are kindly acknowledged. The German Ministry for Research and Education (BMBF) supported the study (grants 03G0186A and $03 \mathrm{G} 0189 \mathrm{~A})$. This is publication no. 2 of the SeaCause project.

\section{Appendix A. Supplementary data}

Supplementary data associated with this article can be found, in the online version, at doi:10.1016/j.epsl.2008.01.047.

\section{References}

Aki, K., 1979. Characterization of barriers on an earthquake fault. J. Geophys. Res. 84, 6140-6148.

Ammon, C.J., 2006. Megathrust investigations (News and Views). Nature 440 (7080), 31-32.

Ammon, C.J., Ji, C., Thio, H.-K., Robinson, D., Ni, S., Hjorleisdottir, V., Kanamori, H., Lay, T., Das, S., Helmberger, D., Ichinose, G., Polet, J., Wald, D., 2005. Rupture process of the 2004 Sumatra-Andaman earthquake. Science 308, 1133-1139.

Ando, M., 1975. Source mechanisms and tectonic significance of historical earthquakes along the Nankai Trough, Japan. Tectonophysics 27, 119-140.

Barckhausen, U., 2006. The segmentation of the subduction zone offshore Sumatra: relations between upper and lower plate. EOS Trans. AGU 87 ((52), Fall Meet. Suppl.), U53A-0029.

Baroux, E., Avouac, J.-P., Bellier, O., Sébrier, M., 1998. Slip-partitioning and fore-arc deformation at the Sunda-Trench, Indonesia. Terra Nova 10 (3), $139-144$.

Bilek, S.L., Schwartz, S.Y., DeShon, H.R., 2003. Control of seafloor roughness on earthquake rupture behaviour. Geology 31, 455-458.

Bilham, R., 2005. A flying start, then a slow slip. Science 308, 1126-1127.

Briggs, R.W., Sieh, K., Meltzner, A.J., Natawidjaja, D., Galetzka, J., Suwargadi, B., Hsu, Y.-J., Simons, M., Hananto, N., Suprihanto, I., Prayudi, D., Avouac, J.-P., Prawirodirdjo, L., Bock, Y., 2006. Deformation and slip along the Sunda megathrust in the great 2005 Nias-Simeulue earthquake. Science 311, 1897-1901.

Cande, S.C., LaBrecque, J.L., Larson, R.L., Pitman, W.C., Golovchenko, X., Haxby, W.F., 1989. Magnetic Lineations of the World's Ocean Basins. LDGO Contribution 4367. AAPG, Tulsa, Oklahoma.

Collot, J.-Y., Marcaillou, B., Sage, F., Michaud, F., Agudelo, W., Charvis, P., Graindorge, D., Gutscher, M.-A., Spence, G., 2004. Are rupture zone limits of great subduction earthquakes controlled by upper plate structures? Evidence from multichannel seismic reflection data acquired across the northern Ecuador-southwest Colombia margin. J. Geophys. Res. 109, B11103. doi:10.1029/2004JB003060.

Cummins, P.R., Baba, T., Kodaira, S., Kaneda, Y., 2002. The 1946 Nankai earthquake and segmentation of the Nankai Trough. Phys. Earth Planet. Inter. 132, 75-87.

Delescluse, M., Chamot-Rooke, N., 2007. Instantaneous deformation and kinematics of the India-Australia Plate. Geophys. J. Int. 168 (2), 818-842. doi:10.1111/j.1365-246X.2006.03181.x.

DeShon, H.R., Engdahl, E.R., Thurber, C.H., Brudzinski, M., 2005. Constraining the boundary between the Sunda and Andaman subduction systems: evidence from the $2002 \mathrm{Mw} 7.3$ Northern Sumatra earthquake and 741 aftershock relocations of the 2004 and 2005 great earthquakes. Geophys. 742 Res. Lett. 32, L24307. doi:10.1029/2005 GL024188.

Deplus, C., Diament, M., Hebert, H., Bertrand, G., Dominguez, S., Dubois, J., 744 Malod, J., Patriat, P., Pontoise, B., Sibilla, J.-J., 1998. Direct evidence of active 745 deformation in the eastern Indian oceanic plate. Geology 26, 131-134. 746

Dewey, J.W., Benz, H., Choy, G., Earle, P., Presgrave, B., Sipkin, S., Tarr, A.C., 747 Wald, D., 2007. Seismicity associated with the Sumatra-Andaman Islands 748 earthquake of 26 December 2004. Bull. Seismol. Soc. Am. 97 (1A), 25-42. 749

Engdahl, E.R., Villasenor, A., DeShon, H.R., Thurber, C., 2007. Teleseismic 750 relocation and assessment of seismicity (1918-2005) in the region of the 751 2004 Mw 9 Sumatra-Andaman and 2005 M 8.7 Nias great earthquakes. 752 Bull. Seismol. Soc. Am. 97, 43-61. doi:10.1785/0120050614.

Fauzi, F., McCaffrey, R., Wark, R.D., Sunaryo, P.Y., Haryadi, P., 1996. Lateral 754 variation in slab orientation beneath Toba Caldera, northern Sumatra. 755 Geophys. Res. Lett. 23, 443-446.

Gahalaut, V.K., Nagarajan, B., Catherine, J.K., Kumar, S., 2006. Constraints on 757 2004 Sumatra-Andaman earthquake rupture from GPS measurements in 758 Andaman-Nicobar Islands. EPSL 242, 365-374.

Graindorge, D., Klingelhoefer, F., Gutscher, M.-A., Sibuet, J.-C., McNeill, L., 760 Henstock, T., Dean, S., Tappin, D., Dessa, J.-X., Singh, S., 2007. Lower 761 plate control of upper plate deformation at the toe of the NW Sumatra 762 convergent margin from swath bathymetry. Geophys. Res. Abstr. 9, 05979763 SRef-ID: 1607-7962/gra/EGU2007-A-05979.

Hall, R., 2002. Cenozoic geological and plate tectonic evolution of SE Asia and the 765 SW Pacific: computer-based reconstructions, model and animations. J. Asian 766 Earth Sci. 20 (4), 353-431.

Henstock, T.J., McNeill, L.C., Tappin, D.R., 2006. Seafloor morphology of the 768 Sumatran subduction zone: surface rupture during megathrust earthquakes? 769 Geology 34, 485-488.

Kamesh Raju, K.A., Murty, G.P.S., Amarnath, Dileep, Kumar, M.L.M., 2007. 771

The west Andaman fault and its influence on the aftershock pattern of the 772 recent megathrust earthquakes in the Andaman-Sumatra region. Geophys. 773 Res. Lett. 34, L03305. doi:10.1029/2006GL028730. 774

Kodaira, S., Takahashi, N., Nakanishi, A., Miura, S., Kaneda, Y., 2000. 775 Subducted seamount imaged in the rupture zone of the 1946 Nankaido 776 earthquake. Sciences 289, 104-106. 777

Korenaga, J., Holbrook, W.S., Kent, G.M., Kelemen, P.B., Detrick, R.S., Larsen, 778 H.-C., Hopper, J.R., Dahl-Jensen, T., 2000. Crustal structure of the southeast 779 Greenland margin from joint refraction and reflection seismic tomography. 780 J. Geophys. Res. 105, 21591-21614.

Krüger, F., Ohrnberger, M., 2005. Tracking the rupture of the $\mathrm{Mw}=9.3$ Sumatra 782 earthquake over $1,150 \mathrm{~km}$ at teleseismic distance. Lett. Nature. doi:10.1038/ 783 nature03696.

784

Ladage, S., Gaedicke, C., Barckhausen, U., Heyde, I., Weinrebe, W., Flueh, E.R., 785 Krabbenhoeft, A., Kopp, H., Fajar, S., Djajadihardja, Y., 2006. Bathymetric 786 survey images structure off Sumatra. EOS Trans. AGU 87 (17), 165.

Lay, T., Kanamori, H., Ammon, C.J., Nettles, M., Ward, S.N., Aster, R.C., Beck, 788 S.L., Bilek, S.L., Brudzinski, M.R., Butler, R., DeShon, H.R., Ekström, G., 789 Satake, K., Sipkin, S., 2005. The Great Sumatra-Andaman earthquake of 790 26 December 2004. Science 308, 1127-1133.

McCarthy, A.J., Elders, C.F., 1997. Cenozoic deformation in Sumatra: oblique 792 subduction and the development of the Sumatran Fault System. In: Fraser, 793 A.J., Matthews, S.J., Murphy, R.W. (Eds.), Petroleum Geology of Southeast 794 Asia. Geol. Soc. Spec. Publ., vol. 126, pp. 355-363. 795

Malod, J.A., Kemal, B.M., 1996. The Sumatra margin: oblique subduction and lateral 796 displacement of the accretionary prism. In: Hall, R., Blundell, D. (Eds.), Tectonic 797 Evolution of Southeast Asia. Geol. Soc. Spec. Publ., vol. 106, pp. 19-28. 798

Milsom, J., 2005. Seismology and neotectonics (Chapter 2). In: Barber, A.J., 799 Crow, M.J., Milsom, J.S. (Eds.), Sumatra. Geol. Soc. Mem, vol. 31, pp. 8-15. 800

Mooney, W.D., Brocher, T.M., 1987. Coincident seismic reflection/refraction 801 studies of the continental lithosphere: a global review (paper 6R0778). Rev. 802 Geophys. Space Phys. 25, 723-742.

Newcomb, K.R., McCann, W.R., 1987. Seismic history and seismotectonics of 804 the Sunda arc. J. Geophys. Res. 92, 421-439.

Rivera, L., Sieh, K., Helmberger, D., Natawidjaja, D., 2002. A comparative 806 study of the Sumatran subduction-zone earthquakes of 1935 and 1984. Bull. 807 Seismol. Soc. Am. 92, 1721-1736. 
ARTICLE IN PRESS

D. Franke et al. / Earth and Planetary Science Letters xx (2008) xxx-xxx

13

809

810

Q2811

812

813

814

815

816

817

818

819

820

821

822

823

824

825

826

827

828

829
Ryan, H.F., Scholl, D.W., 1993. Geologic implications of great interplate earthquakes along the Aleutian arc. J. Geophys. Res. 98, 22135-22146.

Schauer, M., Ladage, S., Weinrebe, W., Berglar, K., Krabbenhoeft, A., Flueh, E., Gaedicke, C., 2006. Morphotectonics of the Sumatra margin - analysis of new swath bathymetry. EOS Trans. AGU 87 (52), U53A-0033 Fall Meeting Supplement.

Schlüter, H.U., Gaedicke, C., Roeser, H.A., Schreckenberger, B., Meyer, H., Reichert, C., Djajadihardja, Y., Prexl, A., 2002. Tectonic features of the southern Sumatra-western Java fore-arc of Indonesia. Tectonics 21, 1047. doi:10.1029/2001TC901048.

Sibuet, J.-C., Rangin, C., Le Pichon, X., Singh, S., Cattaneo, A., Graindorge, D., Klingelhoefer, F., Lin, J.-Y., Malod, J., Maury, T., Schneider, J.-L., Sultan, N., Umber, M., Yamaguchif, H., "Sumatra aftershocks" team, 2007. 26th December 2004 great Sumatra-Andaman earthquake: co-seismic and postseismic motions in northern Sumatra. Earth Planet. Sci. Lett. doi:10.1016/j.epsl.2007.09.005.

Sieh, K., Natawidjaja, D., 2000. Neotectonics of the Sumatran fault, Indonesia. J. Geophys. Res. 105 (B12), 28295-28326.

Simandjuntak, T.O., Barber, A.J., 1996. Contrasting tectonic styles in the Neogene orogenic belts of Indonesia. In: Hall, R., Blundell, D. (Eds.), Tectonic Evolution of Southeast Asia. Geol. Soc. Spec. Publ., vol. 106, pp. $185-201$.
Simons, W.J.F., Socquet, A., Vigny, C., Ambrosius, B.A.C., Haji Abu, S., 830 Promthong, Chaiwat, Subarya, C., Sarsito, D.A., Matheussen, S., Morgan, P., 831 Spakman, W., 2007. A decade of GPS in Southeast Asia: resolving Sunda- 832 land motion and boundaries. J. Geophys. Res. 112, B06420. doi:10.1029/ 833 2005JB003868. 834

Singh, S.C., et al., 2005. Sumatra earthquake research indicates why rupture 835 propagated northward. EOS Trans. AGU 86 (48), 497.

Smith, W.H.F., Sandwell, D.T., 1997. Global seafloor topography from satellite 837 altimetry and ship depth soundings. Science 277, 1957-1962. 838

Spence, W., 1977. The Aleutian are: tectonic blocks, episodic subduction, strain 839 diffusion, and magma generation. J. Geophys. Res. 82, 213-230. 840

Subarya, C., Chlieh, M., Prawirodirdjo, L., Avouac, J.-P., Bock, Y., Sieh, K., 841 Meltzner, A.J., Natawidjaja, D.H., McCaffrey, R., 2006. Plate-boundary 842 deformation associated with the great Sumatra-Andaman earthquake. Nature 843 440, 46-51. 844

Susilohadi, S., Gaedicke, C., Ehrhardt, A., 2005. Neogene structures and 845 sedimentation history along the Sunda forearc basins off southwest Sumatra 846 and southwest Java. Mar. Geol. 219, 133-154.

Yáñez, G., Cembrano, J., 2004. Role of viscous plate coupling in the late Tertiary 848 Andean tectonics. J. Geophys. Res, 109, B02407. doi:10.1029/2003JB002494. 849

Please cite this article as: Franke, D., et al., The great Sumatra-Andaman earthquakes — Imaging the boundary between the ruptures of the great 2004 and 2005

earthquakes, Earth Planet. Sci. Lett. (2008), doi:10.1016/j.epsl.2008.01.047 